\title{
Tuberculosis in children and adolescents: Strategies for social workers' interventions
}

\author{
Norma E. González, M.D., ${ }^{a}$ and Luciana Angueira, B.S. ${ }^{b}$
}

\begin{abstract}
In the care of children and adolescents with tuberculosis (TB), it is necessary to know the difficulties that many families have in accessing health care, obtaining a diagnosis, and receiving a timely treatment. Social workers, along with other members of the health care team, assist in providing access to health care resources and benefits that may favor treatment compliance and strengthen the health of this vulnerable population. Although the purpose of social workers involvement in this disease is to reduce the risk of becoming infected, sick or dying from $\mathrm{TB}$, the current epidemiological situation of this disease in Argentina has faced social workers with the challenge of reconsidering new intervention strategies and revising current objectives. This study addresses their role and proposes actions that may contribute to decreasing TB morbidity and mortality in children and adolescents.

Key words: tuberculosis, social work, children.
\end{abstract}

http: / / dx.doi.org/10.5546/ aap.2017.eng.e391

To cite: González NE, Angueira L.Tuberculosis in children and adolescents: Strategies for social workers' interventions. Arch Argent Pediatr 2017; 115(6):e391-e396.

a. Department of Pulmonary Medicine, Hospital de Niños "Dr. Pedro de Elizalde," Autonomous City of Buenos Aires, Argentina.

b. National Program for the Control of Tuberculosis and Leprosy. Network of Social Workers who conduct tuberculosis interventions in the metropolitan area of Buenos Aires.

E-mail address:

Norma E. González, M.D.: negonza@intramed.net.

Funding:

None.

Conflict of interest: None.

Received: 2-11-2017 Accepted: 5-22-2017 healthy population. ${ }^{2}$ The number of bacilliferous pulmonary TB cases in recent years has not reduced enough to consider that the risk of exposure to $\mathrm{TB}$ in the pediatric population has decreased. ${ }^{2}$

According to the Argentine National Institute of Respiratory Diseases "Emilio Coni," 10713 TB cases (24.8 cases / 100000 inhabitants) were reported in 2015; 9.6\% occurred in children younger than 15 years and $9.3 \%$, in adolescents aged $15-19 .{ }^{2}$

Between 2011 and 2015, there were 117 TB deaths among people younger than 20 years, which accounted for an age-adjusted rate of $0.16 / 100000$ inhabitants. In the 15- to 19-year-old group, the rate was 1.65 times higher than in the 10- to 14-year-old group and 5 times higher than in the group of children younger than 10 years. $^{3}$

Diagnosis in the pediatric population is more difficult, and microbiological confirmation is uncommon. For this reason, the number of pediatric cases is most likely under-recorded. Many children who die from meningitis-, pneumoniaor malnutrition-related complications may have had TB but failed to be reported as such in control programs. ${ }^{4}$

In addition, in our country, the analysis of epidemiological indicators recorded between 1990 and 2011 shows an unequal distribution of TB cases among the different jurisdictions, and the higher TB rates are associated with unfavorable social conditions in the population. ${ }^{5}$

The quality of care provided to patients varies in each location depending on available resources. Providing the areas with the higher concentration of TB cases with the necessary elements for prevention, early detection, and complete 
treatment free of charge is not enough to reduce the rates of disease. ${ }^{6-9}$ The process of caring for children and adolescents with TB also requires knowing the difficulties that many families have in accessing a timely diagnosis and treatment, and the many health care resources and benefits that may favor treatment compliance and strengthen the health of this vulnerable population. ${ }^{10}$

Historically, advances in the medical field and social and economic development have helped to reduce TB prevalence in many countries. ${ }^{7}$ However, the emergence of human immunodeficiency virus (HIV), acquired immune deficiency syndrome (AIDS), and multi-drug resistance have made it clear that the factors that have to be considered in order to control and eradicate TB are much more complicated and should be approached from a wider perspective. ${ }^{4,10-12}$

Publications made by international organizations ${ }^{10,13}$ and task forces ${ }^{6,9}$ have proposed opportunities to conduct interventions related to the social aspects of TB. A multidisciplinary approach helps to improve the quality of care provided to TB patients, but its outcome depends -basically- on the health care staff's attitudes, skills, and competencies. ${ }^{13}$

After having taken part in several training sessions on childhood TB carried out in several Argentinian provinces (in the setting of the Zero Tuberculosis Deaths Initiative conducted by the Argentine Society of Pediatrics and the National Ministry of Health) and based on our work in a pediatric facility and a primary health care center in the metropolitan area of Buenos Aires, we feel the need to focus on this aspect.

Our objective is to describe the role of social workers in the management of children and adolescents with $\mathrm{TB}$ and propose intervention activities that may help to reduce TB morbidity and mortality in this population.

\section{Approach to the tuberculosis problem}

Social workers participate in care areas together with other members of the health care team. Their activities are framed within the concepts related to the health-disease-care process and the right to health care for all, thus facilitating their access to diagnosis and treatment.

Although the purpose of social workers involvement in this disease is to reduce the risk of becoming infected, sick or dying from $\mathrm{TB}$, the current demand for care in relation to this disease, both in outpatient offices and inpatient wards, has faced social workers with the challenge of reconsidering new intervention strategies and revising current objectives. ${ }^{14}$

Traditionally and until today, many times, sick people have been considered mere recipients of medical indications, turning patients into passive subjects. It is understood that patients' encounters with the health care team should be based on an attentive and respectful listening, a place where patients are the protagonists of their treatment and take control of their care in a conscious manner, so that they turn into active subjects capable of expressing their concerns, fears, and knowledge. In the case of infants and young children, many times, their parents or family caregivers feel more comfortable expressing their concerns regarding diagnosis and treatment to social workers than during the visits to the pediatrician.

This does not rule out the responsibility of other health care providers, but gives social workers' interventions a different sense, with a priority focus on individuals' living conditions, experiences, and representations of TB. ${ }^{15}$ Their work refers to the specific involvement each adolescent, child or adult caregiver has in the family, school, and relational setting and their acceptance of the disease.

When proposing the measures to be taken, it should be considered that this is an infectious disease, therefore its management includes, not only the sick person, but also other household members and anyone in long-term contact with the patient, collectively called "contacts." People living together with bacilliferous TB cases are at a higher risk for infection. Such risk is also higher among the contacts of pediatric patients, compared to adults, especially in the case of infants and young children.

Given that this is a "contagious" condition and is considered a "disease of poverty,"12 the associated stigma and discrimination felt by TB patients act as barriers for disease acceptance, ${ }^{16}$ especially when asking the family to attend a health care center to be tested. ${ }^{6}$

Young children, in general, are not infectious; however, older children and adolescents may have a form of TB that is similar to that of adults, i.e., they may also be bacilliferous. In the weeks prior to diagnosis, these patients usually attend school, where they spend several hours a day and expose their classmates and teachers to becoming infected. For this reason, when these cases are observed, their contacts at school should be tested as well, and the uncertainty of being infected 
may somewhat feed fear. At this moment, the information provided to the community by the health care team from different areas is key to demystify TB and minimize the consequences of stigma among children and adolescents with TB. ${ }^{17}$

This disease is also synonymous with a regular and prolonged treatment, an essential requirement for the healing process. Treatment compliance is a necessary requirement for people with TB, understood as a systematic and uninterrupted maintenance of medication, care, and lifestyle conditions indicated as treatment. Social workers focus on health education and on encouraging patient and family involvement to clear any doubt or fear they may have, with a strong emphasis on information. ${ }^{6}$

Such particular or unique characteristics of children/adolescents and their environment shape social workers' interventions, who accompany and support them, and provide information, during hospitalization or outpatient visits. ${ }^{18}$

It is worth noting that, in the process of treatment compliance, the state plays a key role, not only by supplying medications free of charge, which should be warranted at a national level, but also by providing the necessary resources for patients to access care and treatment, as well as to social benefits, free transportation, food, improved living conditions, etc., considering that TB treatment lasts several months, thus affecting the social and working life of patients' families and their quality of life. ${ }^{10,12,13}$

At the institutional level, it is necessary to work on the concept of access as a facilitator of treatment compliance and to ensure the effective implementation of the right to health care. This is in reference to geographical accessibility, the possibility of receiving medications in a timely manner, extended opening hours and more appointments available for follow-up, and to a factor that is especially relevant from the specific

\section{TABLE 1. Screening of contacts}

- To identify each household member and other contacts that may have spent more than 6 hours a day with the TB case.

- Clinical examination, tuberculin test (purified protein derivative, PPD), and chest X-ray in all children and adolescents.

- Clinical examination and chest X-ray in adults.

- Sputum bacilloscopy in adolescents and adults with respiratory symptoms (cough and expectoration for 15 or more days). perspective of social workers: the access gained based on the development of a relationship of trust and respect that allows exchanging knowledge and making joint reflections so that adolescents take control of their care and adults taking care of sick children become strong collaborators with treatment compliance. ${ }^{6}$

TB is usually compared to the tip of an iceberg: ${ }^{19}$ once what underlies the disease is explored, you find poverty, over-crowding, poorly-ventilated houses and workplaces, limited access to health care services, indoor air pollution, HIV/AIDS, addictions, lack of education, and lack of antenatal and pediatric care. Identifying social determinants and factors that favor TB transmission and risk for infection (Figura 1) means gaining access to elements that call for attention and intervention opportunities to reduce TB prevalence, and essentially decrease TB morbidity and mortality among the most vulnerable populations. ${ }^{7,10,16}$

\section{General objective of social workers' interventions}

To reduce the risk of becoming infected, sick or dying from TB through the implementation of prevention and health-related promotion, care, and rehabilitation actions.

\section{Specific objectives}

- To contribute to the visibility of childhood TB as a predominant disease.

- To favor community information and prevention activities.

- To address the problems of children and adolescents with TB and their social and family networks in a comprehensive manner.

- To facilitate access to health care through the coordination and interaction with other health care services and institutions.

- To encourage an interdisciplinary approach to childhood TB.

- To present a social perspective to the health care team in relation to the health-disease-care process, ensure extended access and treatment compliance among children and adolescents.

- To promote participation in teaching and research activities.

\section{Intervention priorities}

Considering an integral health approach, and taking into account the special situations of higher risk for morbidity and mortality, ${ }^{20}$ the following priorities could be established from a social and 
clinical diagnosis standpoint:

- Drug-resistant TB.

- Younger than 5 years.

- Adolescents.

- HIV / AIDS co-infection.

- Tuberculous meningitis.

- Smear-positive pulmonary TB (bacilliferous patients).

- Extrapulmonary TB.

- Complex social struggles.

\section{Activities following tuberculosis diagnosis}

- To conduct interviews aimed at establishing a personalized relationship with patients and their families to gather information about their life, describe TB characteristics and treatment, and the relevance of performing screening tests among contacts. To offer a place to reflect on the impact of diagnosis and a space for support and listening in relation to concerns, distress, fears, myths, and preconceptions.

- To assess the feasibility of access to the health care center and participate in the decisions regarding the treatment modality and place to favor access and compliance, and to promote the right to receive a comprehensive health care among children and adolescents.

\section{Activities during treatment}

- To identify barriers and facilitators of treatment compliance considering the healthdisease-care process of children/adolescents and their families.

- To maintain a close and supportive relationship in case of treatment compliance hurdles by making calls, sending e-mail

FIGURE 1. Risk factors and social determinants related to tuberculosis control

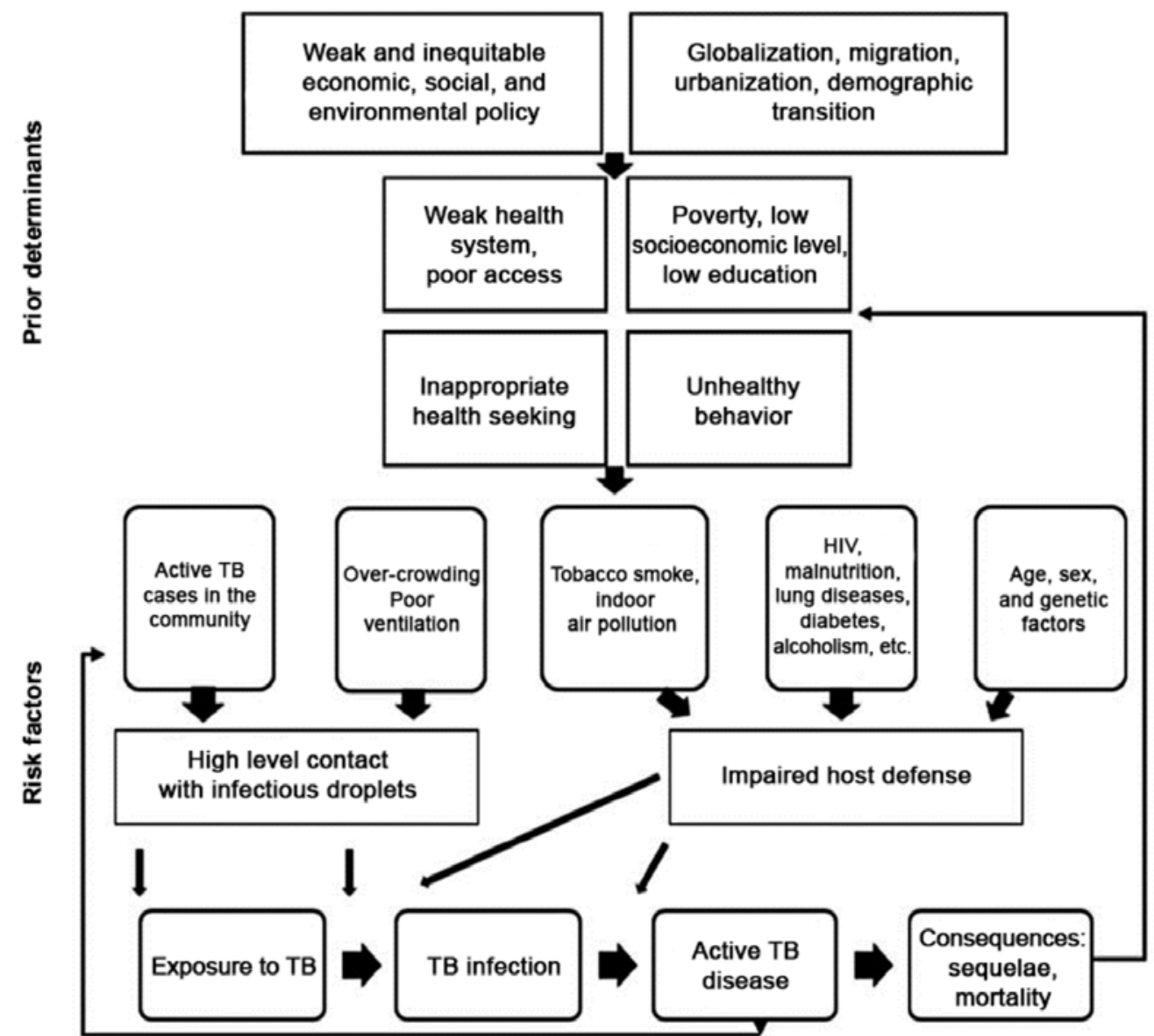

Modified from references 7 and 10.

HIV: human immunodeficiency virus. 
appointments, conducting interviews at home and/or maintaining communication with health care centers or hospitals in the area where patients reside.

- To guide and favor access to the screening of contacts (Table 1) so as to identify the index case, other sick adults and/or other children or adolescents infected or sick with TB.

- To intervene in institutional cases (those occurring in schools, soup kitchens, children's homes, daycare centers) and facilitate communication among health care providers to screen and follow-up contacts.

- To coordinate referrals within the health care system through the specific providers' network for TB care depending on the place of residence.

- To provide guidance on the necessary paperwork to obtain financial and/or social benefits, if applicable.

\section{Activities following treatment completion}

- To strengthen the perception of health care in general and of factors that may influence in the persistence of TB in the family and close contacts, such as nutrition, mother and child checkups, addiction prevention, and early detection of respiratory diseases.

\section{Ongoing activities}

- Preventive health activities aimed at the general community and the pediatric population in particular to provide information on TB and avoid patient stigmatization, thus favoring health promotion and treatment compliance.

- Meetings with the attending health care team to analyze the adopted intervention strategies, assess treatment outcomes (recovery, dropout, death), and regain contact with patients lost to follow-up, providing the perspective of social diagnosis and establishing new lines of action.

\section{CONCLUSIONS}

The presence of $\mathrm{TB}$ in children and adolescents is a direct consequence of exposure to contagious $\mathrm{TB}$ cases sharing their environment. TB control depends on an intricate interaction of biological, political, social, economic, cultural, and environmental factors. It is not feasible to segregate children and adolescents from their setting to protect them from becoming sick or dying from TB. It is necessary to use all available resources to take more effective control measures of TB; social workers' contributions are among the most important ones to this end.

When approaching the difficulties of children and adolescents with TB and their social and family networks, the situations that pose a higher risk for morbidity and mortality and for the lack of treatment compliance should be considered a priority: young children, adolescents, severe TB, HIV / AIDS, complex social struggles.

Interventions could be conducted after diagnosis by offering information and support to adolescents and the parents or family caregivers responsible for infants and young children. During treatment, interventions could provide guidance to favor treatment access and compliance and screening contacts at higher risk for becoming infected and sick with TB. The community could also become involved, information should be provided so as to avoid the stigmatization of children with TB and their family, and to favor health promotion.

\section{Acknowledgments}

We would like to thank the Network of Social Workers who conduct tuberculosis interventions in the metropolitan area of Buenos Aires.

\section{REFERENCES}

1. World Health Organization. Global tuberculosis report 2015. 20thed. Geneva:WHO, 2015. [Accessed on: November $\left.26^{\text {th }}, 2016\right]$. Available at: http://apps.who.int/iris/ bitstream/10665/191102/1/9789241565059_eng.pdf.

2. Notificación de Casos de Tuberculosis en la República Argentina Período 1980-2015. PRO.TB.DOC.TEC. N. ${ }^{\circ}$ 29/16. Santa Fe: INER-ANLIS-MSAL, 2016. [Accessed on: April $8^{\text {th }}$, 2017]. Available at: http:/ / www.anlis.gov. ar/iner/wp-content/ uploads / 2016/11/Notificacionde-casos-de-Tuberculosis-en-la-Republica-ArgentinaPeriodo-1980-2015.pdf.

3. Mortalidad por Tuberculosis en menores de 20 años en Argentina 1980-2015. PRO.TB.DOC.TEC.11/17. Santa Fe: INER-ANLIS-MSAL, 2017. [Accessed on: April $8^{\text {th }}$, 2017]. Availableat:http:/ / www.anlis.gov.ar/iner/wp-content/ uploads / 2016 / 04 / Mortalidad-por-Tuberculosis-enmenores-de-20-años-en-Argentina-1980-2015.pdf.

4. Goosby E. Out of the shadows: shining a light on children with tuberculosis. Int J Tuberc Lung Dis 2015;19(Suppl 1):S1-2.

5. Bossio JC, Arias SJ, Fernandez HR. Tuberculosis en Argentina: desigualdad social y de género. Salud Colectiva 2012;8(Suppl 1):S77-91.

6. Castilla MV, Ferrari Mango C. Tuberculosis y lógicas de cuidado en barrios marginales y vulnerables de Buenos Aires, Argentina. Rev Pilquen Secc Cienc Soc 2015;18(3):36-49.

7. Lönnroth K, Jaramillo E, Williams BG, et al. Drivers of tuberculosis epidemics: The role of risk factors and social determinants. Soc Sci Med 2009;68(12):2240-6.

8. Saunders MJ, Evans CA. Fighting poverty to prevent tuberculosis. Lancet Infect Dis 2016;16(4):395-6.

9. Fuentes-Tafur LA, Ticona Chávez E, Velasco Guerrero JC, et al. El Plan TBCero: Un enfoque integral para el control de la Tuberculosis. Acta Med Per 2012;29(2):104-12. 
10. Lönnroth K, JaramilloE, Williams BG, et al Tuberculosis: the role of risk factors and social determinants. In Blas E, Kurup $\mathrm{S}$, edit. Equity, social determinants and publichealth programmes. Geneva:World Health Organization, 2010:219-42. [Accessed on: January $26^{\text {th }}$, 2017]. Available at: http: / / apps.who.int / iris/bitstream/10665/44289/1/9789241563970_eng.pdf.

11. Grange J M, Gandy M, Farmer P, et al. Historical declines in tuberculosis: nature, nurture and the biosocial model. Int J Tuberc Lung Dis 2001;5(3):208-12.

12. Arango Loboguerrero M. Importancia e impacto social de la tuberculosis en los niños. Medicina (Bogotá) 2015;37(3): 286-93.

13. Williams G, Alarcón E, JittimaneeS, et al. Prácticas óptimas en la atención a los pacientes con tuberculosis. Una guía destinada a los países de bajos ingresos. París: UICTER, 2007. [Accessed on: May 23 ${ }^{\text {rd }}$, 2017]. Available at: http:/ / www.sld.cu/galerias/pdf/sitios/tuberculosis/union_ bestpractice_spanish_web.pdf.

14. Abad Campaña P, Cortés Gimeno V. La tuberculosis, un reto para el trabajador social. Trab Soc y Salud 1999;32: 397-411.

15. Moro Gutierrez L. Condicionantes sociales y culturales en la vivencia de la tuberculosis. Trab Soc y Salud 1999;33: 369-82.

16. Craig GM, Daftary A, Engel N, et al. Tuberculosis stigma as a social determinant of health: a systematic mapping review of research in low incidence countries. Int I InfectDis 2016;56:90-100.

17. García Campos D, Llordes Llordes M, Urgelles Homdedeu $\mathrm{M}$, et al. Intervención social en un brote de tuberculosis en una escuela de primaria. Trab Soc y salud 2004;47:327-30.

18. FernándezFernández MR, Peñafiel Escamez MT, Gutierrez C, et al. Justificación de la presencia de una Trabajadora Social en una Unidad de Tuberculosis. Trab Soc y Salud 2004;47:313-9.

19. Lorenzo RubioJL, González Martín A, Rodríguez González A, et al. Tuberculosis un problema social. Gac Med Espirit 2002; 4(1). [Accessed on: January 28 ${ }^{\text {th }}, 2017$ ]. Available at: http:/ / bvs.sld.cu/revistas/gme/pub/vol.4.(1)_06/ vol.4.1.06.pdf.

20. Comité Nacional de Neumonología e Infectología de la Sociedad Argentina de Pediatría. Criterios de diagnóstico y tratamiento de la tuberculosis infantil. Resumen ejecutivo. Arch Argent Pediatr 2016;114(2):189-190. 